\title{
Metabolic potential of microorganisms associated with the halophyte Aster tripolium L. in saline soils
}

\author{
"Sonia Szymańska, "*Agnieszka Piernik, "Katarzyna Hrynkiewicz
}

\author{
${ }^{*}$ Department of Microbiology, \\ ${ }^{* *}$ Chair of Geobotany and Landscape Planning, \\ Nicolaus Copernicus University in Toruń, Faculty of Biology and Environmental Protection, Lwowska 1, Poland, \\ e-mail: hrynk@umk.pl
}

\begin{abstract}
Increased soil salinization may be caused by a natural (e.g. climate change) and anthropogenic (e.g. improper fertilization and irrigation of agricultural land) factors. The submitted work assumes that microorganisms associated with plant halophytes have a unique metabolic properties that can stimulate plant growth under salt stress.

The aim of the study was to determine the abundance and metabolic biodiversity of endophytic and rhizosphere microorganisms co-existing with Aster tripolium L. and compare them with the properties of soil microorganisms not affected by plant roots at a salty meadows in the vicinity of a soda factory (central Poland). In order to select halotolerant and halophilic microorganisms culture medium was enriched with various concentrations of $\mathrm{NaCl}(0,100,200,400,600 \mathrm{mM} \mathrm{NaCl})$. Total metabolic activity of endophytic, rhizosphere and soil populations was measured to compare the community-level physiological profiles.

Results of our study revealed that bacterial and fungal density increased in the following order: endophytes $<$ soil $<$ rhizosphere. Only the highest concentration $(600 \mathrm{mM})$ of $\mathrm{NaCl}$ decreased the number of microorganisms. The highest total microbial metabolic activity was observed for the rhizosphere, while the activity of endophytes was higher compare to soil populations. To carbon sources which significantly differentiated zones belonged: D-lactose, 4-hydroxybenzoic acid and L-asparagine.

The results are preliminary studies leading to the development of inoculum based on selected microbial halotolerant and halophilic strains which can be used in agriculture and/or recultivation of saline soils.
\end{abstract}

Key words: salinity, inland salt marsh, endophytes, rhizosphere microorganisms, BIOLOG EcoPlates.

\section{Introduction}

Salinization is one of the most widespread processes of soil degradation on the Earth (Ladeiro 2012). Increase of areas with salt-affected soils results in a decrease of productivity, deterioration of environmental health and as the consequence the reduction of economic benefits in agriculture (Silva \& Fay 2012; Ramadoss et al. 2013). Food and Agriculture Organization (FAO 2008) reported that the problem of soil salinity affects over $6 \%$ ( 800 million hectares) of the world's land (saline soil $-3.1 \%$, sodic soil $-3.4 \%$ ) (Bianco $\&$ Defez 2011). Salinity can be a consequence of natural (e.g., geological, hydrological and pedological processes, climate changes and water management) and anthropogenic (e.g., improper methods of irrigation and fertilization, deforestation, pollution by chemicals) factors (Evelin et al. 2009; Bianco \& Defez 2011). The saline soil is considered when the electrical conductivity (EC) of the soil solution is over $4 \mathrm{dS} \cdot \mathrm{m}^{-1}$ (equivalent to $40 \mathrm{mM} \mathrm{NaCl}$ ) (El-Swaify 2000). This level of salinity can significantly limit the growth and development of most plants (El-Swaify 2000).

Salt-resistant or salt-tolerant plants belong to the group of halophytes. This small group of plants consists only of few plant species which can grow in extremely unfavoura- 
ble conditions, e.g.: salt marshes, estuaries, cliffs, dunes or deserts (Gago et al. 2011). The unique properties of these plants can be applied in many industrial and ecological processes (Gago et al. 2011) and from this point of view constitute a new potential in modern technologies used in agriculture and/or environmental protection. Halophytes have evolved several adaptive mechanisms which allow them to overcome saline stress (Silva \& Fay 2012). To the basic mechanisms of their adaptation belong e.g., production of compounds increasing osmotic pressure in the cytoplasm and/or the exclusion of $\mathrm{Na}^{+}$from the plant cells. Moreover, indirect mechanisms (analyzed in this work) are considered as association of plants with endophytic and rhizosphere microorganisms which can improve plant growth in stress conditions (Sgroy et al. 2009).

Sea aster (Aster tripolium L.) is a perennial halophyte from the family of Asteraceae (Andersone et al. 2012) growing in Europe at areas with a wide range of salinity (concentration of $150-300 \mathrm{mM} \mathrm{NaCl}$ limits its growth) (Neto et al. 2006). A. tripolium belongs to the group of protected plant species (Kepel et al. 2013). Due to the high genetic variability of this plant and in the consequence of its physiological adaptation to changing environmental conditions this species is considered as a model plant in the investigation of salt stress (Andersone et al. 2012). Sea aster belongs to human consumption plants due to the high content of beneficial compounds e.g.: carbohydrates, proteins, calcium, potassium, magnesium, iron, manganese, copper, vitamin C, beta-carotene and fiber (Gago et al. 2011).

Plant productivity, especially at unfavorable areas, depends mostly on the level of available nutrients, which is closely related to microbiological processes of synthesis and mineralization, causing increased amount of organic matter in the soil (Moradi et al. 2011). Microorganisms associated with the rhizosphere or interior of plant roots (endophytes) may contribute to the promotion of plant growth in stress conditions. However, high salinity of the soil can affect the abundance and metabolic activity of soil microorganisms (Glick 2012). Some microorganisms evolved mechanisms of osmoadaptation that allow them to survive under saline conditions (Upadhyay et al. 2012). Halotolerant microorganisms can accumulate in the cytoplasm osmoprotectants i.e. sugars, free amino acids, quaternary ammonium compounds, which can be synthesized de novo or uptaken from the environment (Gontia-Mishra \& Sharma 2012). Microorganisms can also alleviate salt stress of host plants by production of exopolysaccharides (EPS) and/or biofilm formation, what correlate with the restriction of sodium uptake by plants (Milosević et al. 2012). Moreover, some rhizosphere and endophytic microorganisms associated with agricultural plant can promote plant growth by increased availability of nutrients e.g. phosphorus, nitrogen, iron and synthesis of phytohormones (indole-3 acetic acid, gibberellic acid, cytokinin) or biological control of disease (Kloepper et al. 1999; Sgroy et al. 2009).

The aim of our study was to evaluate the abundance and metabolic activity of microorganisms (bacteria and fungi) associated with roots (endophytes) and rhizosphere of A. tripolium L. growing at salt-affected site and compare with soil microorganisms not affected by plants. We hypothesized that halophytes can stimulate the density and activity of microbial populations associated with their roots in the saline soil and well adapted group of halotolerant microorganisms possesses unique metabolic properties which can influence the growth of host plants under salt stress.

\section{Materials and methods}

\subsection{Site description, test plant and sampling}

The test site was localized in the central part of Poland at the meadows in the vicinity of a soda factory (Soda Poland CIECH SA) in Inowrocław (N 52 48, E 18¹5). The factory was founded in 1879 and works till today. Improper storage of industrial wastes from soda production, wastewater infiltrated into the soil led to the land degradation causing its alkalinization and salinization (Piernik 2006). Meadows are located in a short distance from the factory and are characterized by heterogeneous soil salinity. A large part of these salt meadows is rich in halophytic plant species: Aster tripolium, Salicornia europaea, Spergularia salina, Glaux maritima, Triglochin maritimum, Puccinellia distans and Atriplex prostrata ssp. prostrata var. salina, while less saline areas are inhabited by: Bolboschoenus maritimus, Lotus tenuis, Tetragonolobus maritimus, Festuca rubra and Trifolium fragiferum. Based on Polish soil classification, the soil was classified as mineral-organic (org. matter: 10-20\%). Salinity was related to the presence of chloride anions $\left(\mathrm{Cl}^{-}>>\mathrm{SO}_{4}{ }^{2-}>\mathrm{HCO}_{3}{ }^{-}\right)$and calcium cations $\left(\mathrm{Ca}^{2+}>\mathrm{Na}^{+}>>\mathrm{Mg}^{2+}>\mathrm{K}^{+}\right)$(Piernik 2012). Salinity values measured at the test site as electrical conductivity of a saturated extract $\left(\mathrm{EC}_{\mathrm{e}}\right)$ was $55 \mathrm{dS} \cdot \mathrm{m}^{-1}(550$ $\mathrm{mM} \mathrm{NaCl}$ ) (October 2012). Material for research - five samples of $A$. tripolium L. (shoots and roots with adjacent soil: $20 \mathrm{~cm}$ × $20 \mathrm{~cm}$ x $20 \mathrm{~cm}$ soil cubes) and three soil samples from the area devoid of any plants was collected in autumn 2012 by using sterile tools and placed in a separate plastic bags to avoid contamination. Samples were transported to the laboratory and analyzed immediately.

\subsection{Isolation and quantification of bacterial and fungal strains}

Microorganisms were isolated from three zones: the interior of plant roots (endophytes - E), the rhizosphere (soil closely adjacent to the roots $-\mathrm{R}$ ), and soil (not affected 
by plant growth $-\mathrm{S})$. Samples were averaged in sterile lab conditions and one representative sample $(10 \mathrm{~g})$ for each zone was taken for further analysis. Plant roots were separated and washed thoroughly with $2 \% \mathrm{NaCl}$ solution, dried using sterile filter paper, weighed and placed in a sterile flask. Then, roots were surface sterilized in $100 \mathrm{ml}$ of $15 \%$ hydrogen peroxide by shaking $(5 \mathrm{~min})$. After three times of washing with $100 \mathrm{ml}$ of $2 \% \mathrm{NaCl}$ solution roots were placed in a sterile mortar and homogenized with the use of a sterile pestle. The obtained material was a starting sample for preparation of serial dilutions. The liquid obtained after the second washing was used to assess the sterilization process. Only successfully sterilized roots were used to examine the density of endophytes. To estimate the density of microorganisms inhabiting three analyzed zones of isolation: roots - endophytes [E], rhizosphere [R], soil [S], serial dilutions technique $\left(10^{-1}\right.$ to $\left.10^{-5}\right)$ in $2 \% \mathrm{NaCl}$ solution was used. To evaluate the growth rate of microorganisms three different solid media were used: nutrient agar (Difco) and R2A medium (Difco) supplemented with nystatin $(100 \mathrm{mg} / \mathrm{l})$ - for determination of bacteria and Martin medium (BTL) supplemented with tetracycline $(30 \mathrm{mg} / \mathrm{l})$ - for determination of fungi. For selection and determination of the total number of halophilic and halotolerant microorganisms various concentrations of $\mathrm{NaCl}(0,100$, 200, 400, $600 \mathrm{mM}$ ) were used in solid media. Halotolerant microorganisms can grow under salt stress (to $200 \mathrm{mM}$ $\mathrm{NaCl}$ ) but does not necessarily require salinity for growth, and halophilic microorganisms require osmotic stress to survive (Oren 2006). To assess bacterial density, different dilution ranges were used (E: $10^{-1}$ and $10^{-2}$, R: $10^{-4}$ and $10^{-}$ ${ }^{5}, \mathrm{~S}: 10^{-3}$ and $\left.10^{-4}\right)$. For each variant of experiment three replications (360 plates in total) were used. To asses fungal density only two different dilutions (E, R and $\mathrm{S}-10^{-1}$ and $\left.10^{-2}\right)$ were used and carried out in three replications (180 plates in total).

Bacteria and fungi were incubated for 7 days at $26^{\circ} \mathrm{C}$. The number of colonies of microorganisms was estimated twice: at 3 and 7 days. For analysis of the results one representative dilution (number of microbial colonies on a Petri dish in the range 30-300) for each investigated variant was selected. The number of microorganisms was expressed as a colony forming units (c.f.u.) per gram of dry biomass/soil Based on morphological features 60 bacterial and 40 fungal colonies were selected and subjected to $16 \mathrm{~S}$ rDNA (bacteria) and ITS (fungi) identification prior to further studies.

\subsection{Total metabolic activity of microbial populations}

Determination of the total metabolic activity was carried out for three analyzed variants of experiment: E, R, S. Analysis was performed by phenotype microarray technique using BIOLOG EcoPlates ${ }^{\mathrm{TM}}$. EcoPlates contain 31 various carbon substrates (most commonly metabolized by environmental microbes) and a control well (without a carbon source) in three replications (Classen et al. 2003). Tested carbon sources belong to seven groups of compounds: (1) amino acids, (2) carbohydrates, (3) carboxylic acids, (4) phenolic acids, (5) polymeric, (6) amines and amides, (7) miscellaneous (Campbell et al. 1997). This method is used to study the metabolic activity of heterotrophic microbial populations (Merkl \& Schultze-Kraft 2006). Capacity and level of utilization of various carbon sources by microbial communities allow to generate a physiological profile (community-level physiological profiles - CLPP), referred as the metabolic fingerprinting (Frąc et al. 2012). Increased metabolic activity of microorganisms in the presence of specific carbon source results in a violet color, which is a consequence of the reduction of tetrazolium violet to purple colored formazan.

For inoculation BIOLOG EcoPlates one selected dilution $\left(10^{-3}\right.$, serial dilutions were prepared in $\left.2 \% \mathrm{NaCl}\right)$ was used. The suspension for inoculation was placed in sterile Petri dishes and aliquots $(150 \mu \mathrm{l})$ were applied onto the microarray plates and incubated for 7 days at $26^{\circ} \mathrm{C}$. The optical density (absorbance at $590 \mathrm{~nm}$ ) in the wells was measured at 24-hour intervals using Biolog Micro Station plate reader.

The total metabolic activity of microbial populations isolated from the three zones of isolation (E, R, S) was expressed as Average Well Color Development (AWCD). AWCD value refers to the total metabolic activity of microorganisms isolated from the specified source, and has been calculated according to the formula proposed by Garland and Mills (1991):

$\mathrm{AWCD}=\Sigma(\mathrm{C}-\mathrm{R}) / \mathrm{n}$,

where: $\mathrm{C}$ is the optical density obtained for the well containing a carbon source, $\mathrm{R}$ is the absorbance value obtained for the control wells, $\mathrm{n}$ - number of the tested carbon sources (on the EcoPlates $n=31$ ). The difference $(\mathrm{C}-\mathrm{R})$ is defined as a net absorbance value.

\subsection{Statistical analysis}

For the determination of differences in the density of bacterial and fungal strains depending on the zones of isolation $(\mathrm{E}, \mathrm{R}, \mathrm{S})$ and a variant of $\mathrm{NaCl}$ concentration $(0,100$, 200, 400, $600 \mathrm{mM} \mathrm{NaCl}$ ) ANOVA with parametric Newman-Keuls test as post-hoc comparison using Statistica software (Statistica ver. 7, Statsoft) were used. Evaluation of the ability and level of utilization of different carbon sources was carried out by using multivariate statistical techniques like a principal components analysis (PCA) and discriminant analysis (CVA). Principal components analysis and discriminant analysis were carried out using Canoco software (Canoco 4.5 version, ter Braak \& Šmilauer 2002). 


\section{Results}

\subsection{Density of microorganisms}

All investigated in the experiment factors: zone of isolation $(\mathrm{E}, \mathrm{R}, \mathrm{S})$ and the concentration of $600 \mathrm{mM}$ of $\mathrm{NaCl}$ used in the culture medium significantly influenced the density of bacteria (Table 1, Fig. 1) and fungi (Table 2, Fig. 2). The total number of microorganisms isolated from three tested zones of isolation: endophytes (E), rhizosphere (R) and soil (S) revealed twice-four times higher number of bacteria (2.29 to $6.70 \log _{10}$ c.f.u. per $g$ dry weight) compare to fungi ( 0 to $0.72 \log _{10}$ c.f.u. per $g$ dry weight). The highest number of microorganisms was observed in the rhizosphere bacteria: 6.36-6.70 $\log _{10}$ c.f.u. per g dry weight and fungi: 4.05 to $4.21 \log _{10}$ c.f.u. per g dry weight, while the lowest density was characteristic for endophytes - bacteria: 2.49 to $3.02 \log _{10}$ c.f.u. per $g$ dry weight and fungi: 0 to 1.33 $\log _{10}$ c.f.u. per g dry weight (Table 1 and 2, Fig. 1 and 2). Since the contribution of fungi in colonization of roots (E) was very low, interpretation of these results should be very careful. Density of soil microorganisms for both investigated group of microorganisms (bacteria and fungi) was between the levels of the two previously mentioned zones (R and E) and obtained for bacteria: 4.10 to $4.57 \log _{10}$ c.f.u. per $\mathrm{g}$ dry weight and for fungi: 0.72 to $1.26 \log _{10}$ c.f.u. per $\mathrm{g}$ dry weight). We have revealed a significant effect of $\mathrm{NaCl}$ concentration used in the culture medium on the number of isolated microbial strains. In general, the lowest number of cultivable bacterial and fungal strains was observed in $600 \mathrm{mM} \mathrm{NaCl}$ concentration (in case of fungi also in
Table 1. ANOVA MS effect, $F$ value and P level for density of tested bacteria after 7 days of cultured on R2A medium [c.f.u. (g dry weight $)^{-1}$ ] of site, zone of isolation and $\mathrm{NaCl}$ concentration and Newman-Keuls post hoc comparison of amount of fungi. Significant differences are marked by different letters

\begin{tabular}{|c|c|c|c|}
\hline Parmeter & MS effect & $\mathrm{F}$ & $\mathrm{p}$ level \\
\hline (1) Zone & 53.711 & 4300.94 & 0.000 \\
\hline (2) $\mathrm{NaCl}$ & 0.072 & 5.74 & 0.001 \\
\hline (3) Zone* $\mathrm{NaCl}$ & 0.021 & 1.68 & 0.144 \\
\hline Error & 0.096 & & \\
\hline \multicolumn{4}{|c|}{ Newman-Keuls post-hoc comparison } \\
\hline \multirow{3}{*}{ (1) Zone } & \multicolumn{2}{|c|}{ Endophytes } & $2.7297 \mathrm{a}$ \\
\hline & \multicolumn{2}{|c|}{ Rhizosphere } & $6.5177 \mathrm{c}$ \\
\hline & \multicolumn{2}{|c|}{ Soil } & $4.4353 \mathrm{~b}$ \\
\hline \multirow{5}{*}{ (2) $\mathrm{NaCl}$} & \multicolumn{2}{|c|}{0} & $4.6611 \mathrm{~b}$ \\
\hline & \multicolumn{2}{|c|}{100} & $4.5985 \mathrm{~b}$ \\
\hline & \multicolumn{2}{|c|}{200} & $4.5972 \mathrm{~b}$ \\
\hline & \multicolumn{2}{|c|}{400} & $4.5405 \mathrm{~b}$ \\
\hline & \multicolumn{2}{|c|}{600} & $4.4240 \mathrm{a}$ \\
\hline
\end{tabular}

the concentration 200 of $\mathrm{mM} \mathrm{NaCl}$ ) (Table 1 and 2). This might indicate the presence of significantly lower number of halophilic bacteria, which are known to survive at high salt concentrations.

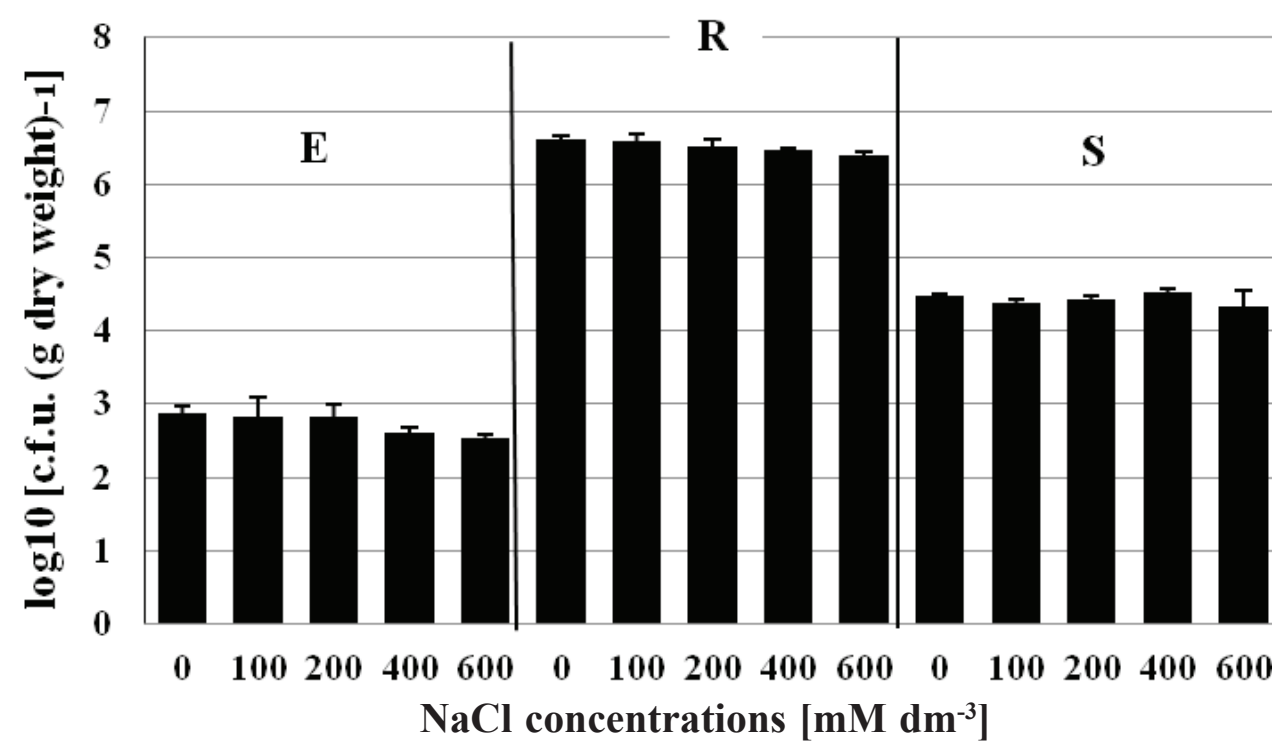

Figure 1. The total number of bacteria [expressed as $\log _{10}$ c.f.u. per $1 \mathrm{~g}$ of dry weight] isolated from interior of roots (E), rhizosphere (R) and soil (S) of A. tripolium. Mean values $(n=3) \pm$ $\mathrm{SD}$ for given variants of isolation and $\mathrm{NaCl}$ concentrations marked 


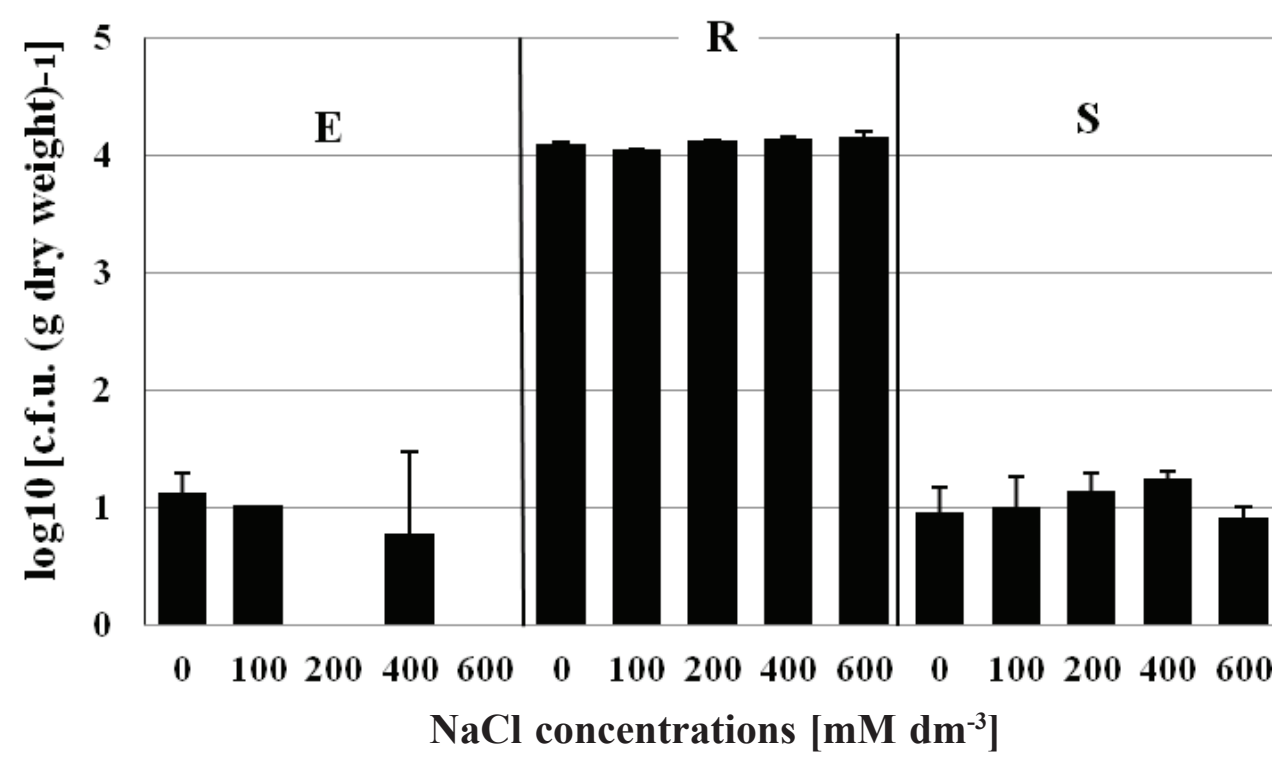

Figure 2. The total number of fungi [expressed as $\log _{10}$ c.f.u. per $1 \mathrm{~g}$ of dry weight] isolated from interior of roots (E), rhizosphere (R) and soil (S) of A. tripolium. Mean values ( $\mathrm{n}=3) \pm \mathrm{SD}$

Table 2. ANOVA MS effect, $\mathrm{F}$ value and P level for density of tested fungi after 7 days of cultured on Martin medium [c.f.u. (g dry weight) $)^{-1}$ ] of site, zone of isolation and $\mathrm{NaCl}$ concentration and Newman-Keuls post hoc comparison of amount of fungi. Significant differences are marked by different letters

\begin{tabular}{|c|c|c|c|}
\hline Parameter & MS effect & $\mathrm{F}$ & $\mathrm{p}$ level \\
\hline (1) Zone & 28.257 & 110.5205 & 0.000 \\
\hline (2) $\mathrm{NaCl}$ & 0.391 & 1.5292 & 0.001 \\
\hline (3) $\mathrm{Zone}^{*} \mathrm{NaCl}$ & 0.139 & 0.5455 & 0.000 \\
\hline Error & 0.256 & & \\
\hline \multicolumn{4}{|c|}{ Newman-Keuls post-hoc comparison } \\
\hline \multirow{3}{*}{ (1) Zone } & \multicolumn{2}{|c|}{ Endophytes } & $0.5885 \mathrm{~b}$ \\
\hline & \multicolumn{2}{|c|}{ Rhizosphere } & $4.1215 \mathrm{c}$ \\
\hline & \multicolumn{2}{|c|}{ Soil } & $1.0562 \mathrm{a}$ \\
\hline \multirow{5}{*}{ (2) $\mathrm{NaCl}$} & \multicolumn{2}{|c|}{0} & $2.0676 \mathrm{~b}$ \\
\hline & \multicolumn{2}{|c|}{100} & $2.0277 \mathrm{~b}$ \\
\hline & \multicolumn{2}{|c|}{200} & $1.7580 \mathrm{a}$ \\
\hline & \multicolumn{2}{|c|}{400} & $2.0645 \mathrm{~b}$ \\
\hline & \multicolumn{2}{|c|}{600} & $1.6925 \mathrm{a}$ \\
\hline
\end{tabular}

\subsection{Phenotype microarray analysis}

Examination of the total microbial metabolic activity was performed by phenotype microarray analysis. Obtained results revealed significant differences in AWCD values and in kinetics of utilization of different carbon sources depending on the zone (E, R, S) of isolation (Fig. 3). The highest AWCD (measured as the kinetic curve) was observed for the rhizosphere microorganisms (0.0013$0.0410)$. The total metabolic activity of endophytes was at lower level than rhizosphere microorganisms (0.0002$0.0265)$ and significantly higher compared to the metabolic activity of soil microorganisms (0.0004-0.0119) $(\mathrm{R}>\mathrm{E}>$ S) (Fig. 3). Furthermore, time necessary to initiate enzymatic activity by endophytic and soil microorganisms was slightly longer ( 48-72h) than by rhizosphere microorganisms ( 24-48h) (Fig. 3).

PCA analysis revealed that microbial activity (based on the pattern of utilized carbon sources) of populations from three analyzed zones (E, $\mathrm{R}$ and $\mathrm{S}$ ) of $A$. tripolium was divided into three distinct groups (Fig. 4). Rhizosphere microorganisms were positively correlated with the majority of investigated carbon sources (13 from 30 investigated in total), what suggests their broad potential to exploit different nutrients or higher biodiversity of this microbial population. Endophytic and soil microorganisms were found to be associated with distinct carbon sources - endophytic population was correlated with D-galacturonic acid and soil population with 2-hydroxybenzoic acid (Fig. 4). Separation of endophytic and soil populations from rhizosphere populations and comparative PCA analysis revealed high- 


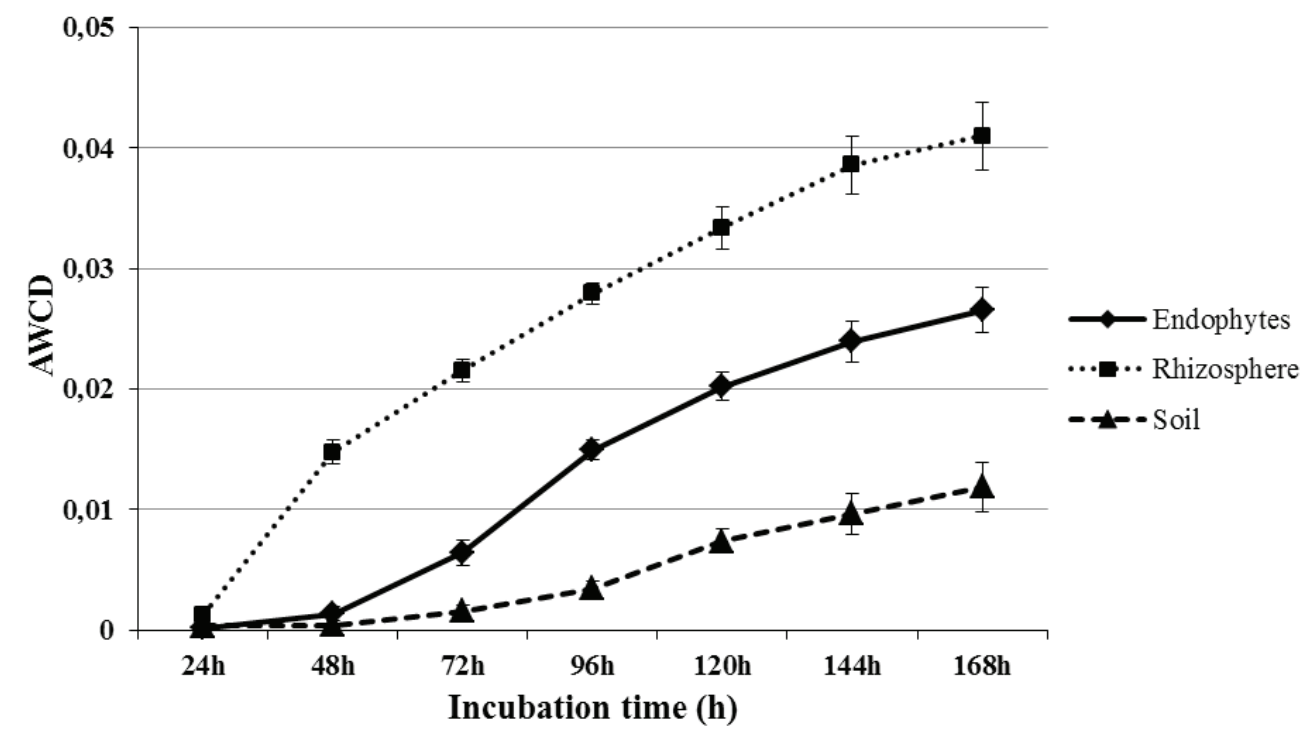

Figure 3. Kinetics of total metabolic activity of microorganisms associated with roots (endophytes), rhizosphere and soil at test site expressed as average well color development (AWCD) and measured at 7 different time of incubation

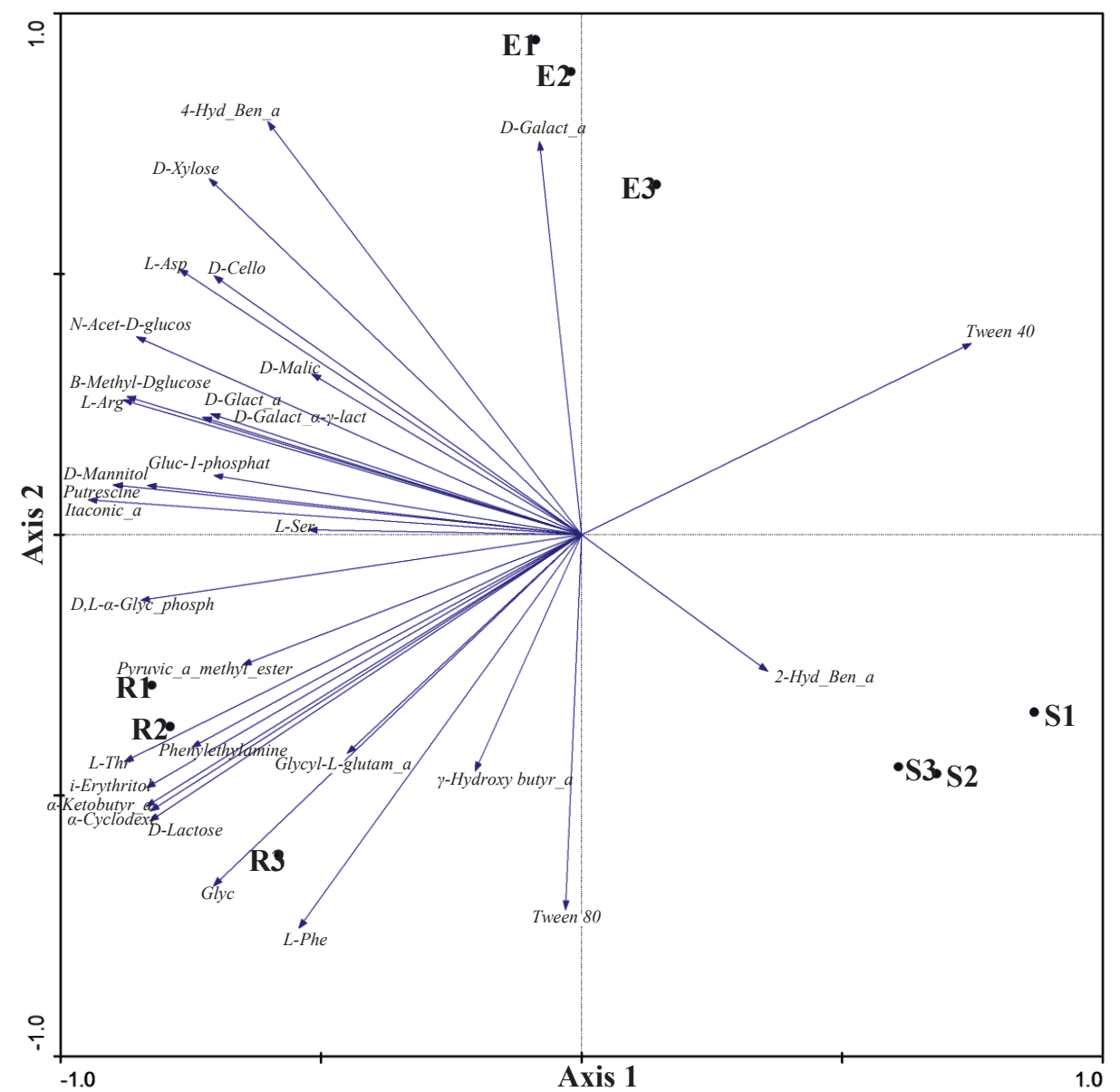

Figure 4. PCA ordination results of utilization of different carbon sources by microbial population of A. tripolium. $\mathrm{R}$ - rhizosphere, $\mathrm{E}$ - endophytes, $\mathrm{S}$ - soil microorganism 


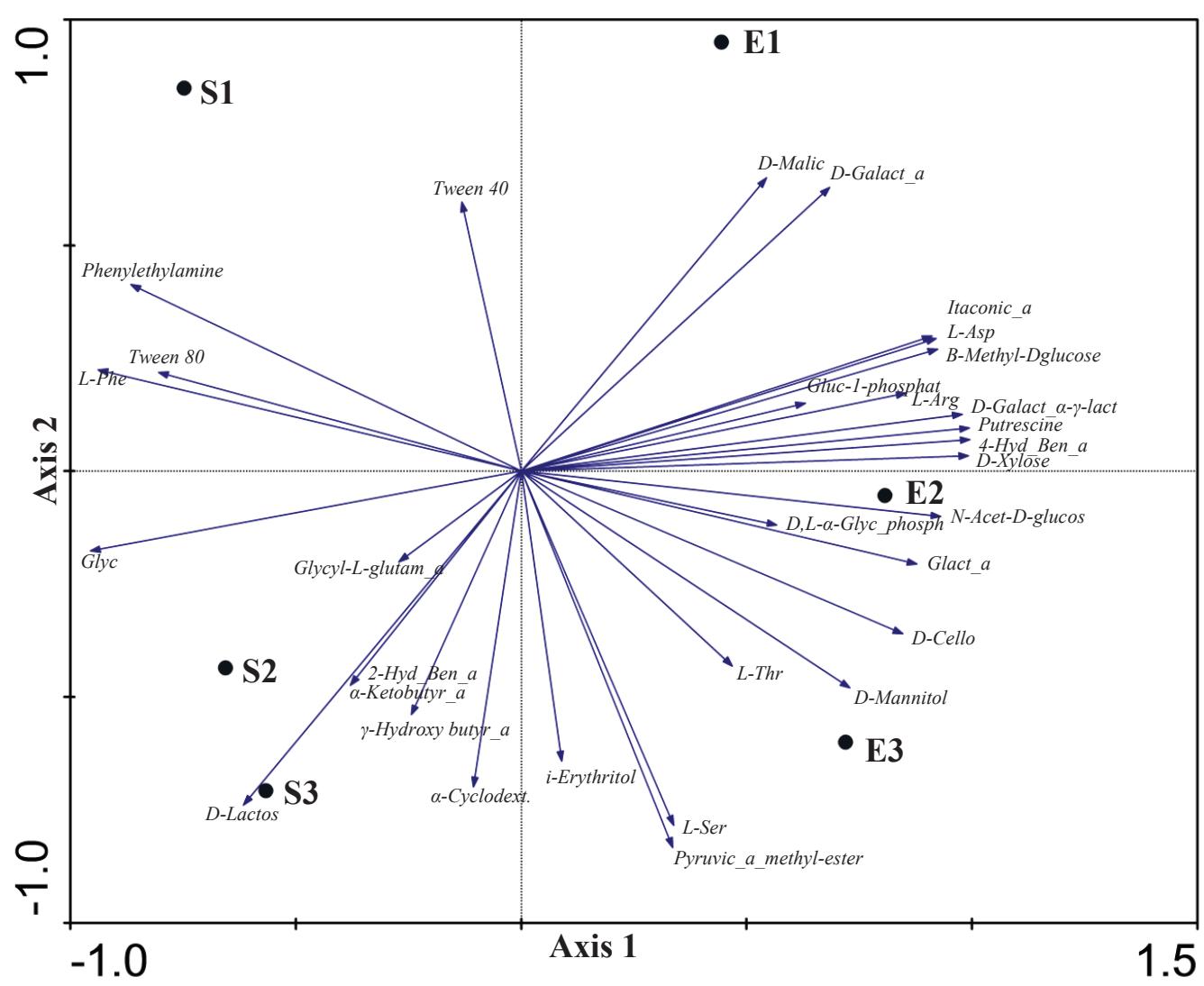

Figure 5. PCA ordination results of utilization of different carbon sources by endophytes (E) and soil (S) microbial population of A. tripolium

er tendency of endophytes for utilization of amino acids (4 of 6 tested), carbohydrates (6 of 7 examined), carboxylic acids (5 of 6 tested) and miscellaneous (3 of 3 tested) compare to soil microorganisms. Soil microorganisms were positively correlated with all studied polimeric (4 of 4 tested) (Fig. 5).

Discriminant analysis (CVA) of E, R and S microorganisms was based on the absorbance values obtained for all carbon sources. Forward selection procedure and the Monte Carlo permutation test allowed to select 3 carbon sources significant in differentiation of microbial communities from the selected variants (three zones of isolation: E, R, E) (Table 3). The most important in discrimination between zones were D-lactose, 4-hydroxybenzoic acid and L-asparagine, which explain $49.5 \%, 48 \%$ and $1 \%$ of the data variation, respectively. The significantly higher utilization level of D-lactose was observed for rhizosphere population, while 4-hydroxybenzoic acid was preferably metabolized by endophytic microorganisms. Significantly higher ability for utilization of L-asparagine was characteristic for endophytic (E) and rhizosphere microorganisms (R).
Table 3. Effect of three different microbial populations (E, R, $\mathrm{S})$ on their metabolic properties - discriminant analysis (CVA)

\begin{tabular}{|l|c|c|}
\hline $\begin{array}{l}\text { Variable } \\
\text { Carbon sources }\end{array}$ & $\mathrm{p}$ & $\begin{array}{c}\text { \% variation } \\
\text { explained }\end{array}$ \\
\hline (1) D-Lactose & 0.010 & 49.5 \\
\hline (2) 4-Hydroxybenzoic acid & 0.004 & 48 \\
\hline (3) L-Asparagine & 0.004 & 1 \\
\hline
\end{tabular}

\section{Discussion}

At investigated in our work saline area we have revealed significantly higher density of bacteria than fungi, what is in line with the results obtained by other authors (Chowdhury et al. 2011; Sardinha et al. 2003). This shows a clear evidence to a higher sensitivity of fungi to salinity than bacteria. However, shifts in the density of bacterial and fungal communities can also be associated with differences in soil properties, e.g. soil texture, soil $\mathrm{pH}$ and soil nitro- 
gen availability (Lauber et al. 2008). In general, we have observed the lowest number of microorganisms at concentration of $600 \mathrm{mM} \mathrm{NaCl}$, what might be due to their adaptation to their natural salinity in the investigated environment $(550 \mathrm{mM} \mathrm{NaCl})$. Negative effect of increased salinity on the number of microorganisms was suggested by many authors (Milosević et al. 2012; Tripathi et al. 2006).

The results of our study showed significantly higher number of microorganisms in the rhizosphere compare to other investigated zones: interior of the halophytic roots and soil not influenced by any plant. The highest density of rhizosphere microorganisms compare to soil microorganisms is typical, as a consequence of exudates secreted by plant roots, which contain several valuable for microorganisms nutrients e.g., amino acids, sugars, organic acids, and others (Glick 2012; Bianco \& Defez 2011). Additionally, a wealth of compounds present in the rhizosphere stimulate chemotaxis of microorganisms in direction of plant roots (Bianco \& Defez 2011). Moreover, the highest density of rhizosphere microorganisms may be correlated with their greatest role in alleviation of abiotic stresses of plants compared to endophytic and soil microorganisms (Milosević et al. 2012). The rhizosphere microorganisms can stimulate the synthesis of osmoprotectors and heat shock proteins by plants in a salt environment (Milosević et al. 2012). It was presumed that rhizosphere bacteria can play a pivotal role in reducing salt stress of plants by reducing effect of physiological drought caused by decreased water availability (Upadhyay et al. 2012).

The lowest density of bacteria and fungi we have observed in case of endophytes. This is in line with suggestions of Kloepper et al. (1999) and Zinniel et al. (2002). The density of endophytic bacteria obtained in our work was between 2.49 and $3.02 \log _{10}$ c.f.u. per g dry weight. Kobayashi and Palumbo (2000) who investigated the density of endophytic bacteria of alfalfa, sweet corn, sugar beet, squash, cotton, and potato revealed its level between of 2.0 to $6.0 \log _{10}$ c.f.u. per g. However, the density of endophytes can depends also on different factors, e.g.: plant species, plant age, the type of studied tissue and test site (Zinniel et al. 2002). The lowest density of endophytes, compare to rhizosphere and soil microorganisms, can be the result of a very specific niche that is the interior of plant tissues. Endophytic microorganisms must be compatible with the host plants and have a unique metabolic properties to avoid to be recognized as pathogens (Long et al. 2008). Endophytes colonizing specific organs and tissues may possess different function which promote plant growth. Long et al. (2008) reported that endophytic bacteria colonizing apoplast of plant roots contain high level of ACC deaminase. There are many research papers emphasizing important role of both bacterial and fungal endophytes as a natural component of plants involved in the mitigation of abiotic stress (e.g. Bianco \& Defez 2011).
BIOLOG EcoPlates method is characterized by a high sensitivity and reproducibility which permit an evaluation of specific populations of microorganisms and to generate their metabolic pattern - community-level physiological profile (CLPP) (Classen et al. 2003). Since dehydrogenase activity of microorganisms (which is evaluated by EcoPlates BIOLOG technique) can be substantially affected by the salinity of the environment (Tripathi et al. 2006), we have optimized concentration of $\mathrm{NaCl}$ in the solution used in our experiments to the most natural conditions present in the environment, optimal for an unique microbal species of investigated group of halotolerant and halophilic microorganisms. Before final examination, we evaluated the result of several solutions on the effect of total metabolic activity of microbial populations e.g.: water, physiological saline solution $(0.85 \% \mathrm{NaCl})$ and $2 \% \mathrm{NaCl}$. We have observed lack of metabolic activity in case of water and physiological saline solution, that might be a consequence of the specificity of microbial population investigated at saline area. Finally, for our analysis we have chosen $2 \%$ $\mathrm{NaCl}(\sim 400 \mathrm{mM} \mathrm{NaCl})$ solution. Above concentration of the solvent does not affect the reliability of the measurements using EcoPlates. It was reported that concentrations which excess $15 \% \mathrm{NaCl}$ might inhibit the reaction, since high concentration of $\mathrm{NaCl}$ can interfere with the indicator dye - tetrazolium violet (Litchfield \& Gillevet 2002).

Our results show that the highest metabolic activity and potential for utilization of different carbon sources was observed for rhizosphere microorganisms. Metabolic activity of endophytic microorganisms was lower compare to rhizosphere but higher compare to soil microorganisms. Similarly to our results, Yang et al. (2013) revealed higher metabolic activity (using the same BiologEco plate technique) of rhizosphere microorganisms compare to soil populations. Our work is the first report on the metabolic activity of endophytes, this is why comparison with the results of other scientists is not possible. Metabolic properties of rhizosphere populations are the consequence of more favorable living conditions in the root zone compare to the bulk soil (Bianco \& Defez 2011; Timmusk et al. 2011). Rhizosphere microorganisms play a crucial role in the regulation of the biological properties of the soil, plant health and enhance osmotic stress tolerance of plants (Yang et al. 2011). One of the various mechanisms involved in mitigation of abiotic stress of plants by microorganisms is active secretion of microbial compounds (proteins, polysaccharides, lipopolysaccharides and cell surface agglutinin) to the rhizosphere, which enhances soil aggregation and in the consequence improves water stability (Timmusk et al. 2011). Breitkreuz et al. (2003) reported that the plant roots growing under salt stress secrete to the rhizosphere carboxylic acids which increase the level of malic acid in oxygen deficiency conditions. Our research shows that both the rhizosphere as well as endophytic microorganisms exhibit 
significantly higher ability to utilize carboxylic acids compare to soil microbial population.

To maintain stable symbiosis with host plant, endophytes must display specific metabolic activity consisting of releasing different extracellular enzymes enabling them to live inside the plant tissues (Wang \& Dai 2011). Endophytes play an important role in plant growth promotion, particularly in abiotic stress conditions, and participate in the processes of biosynthesis, biotransformation and biodegradation of various compounds (Wang \& Dai 2011). Our analysis revealed a wider range of utilized carbon compounds by endophytes compare to microorganisms present in the soil. This may be caused by low biodiversity of microorganisms present in the soil, since salt stress negatively affect changes in the microbial communities.

Salinisation at the landlocked salt-affected sites changes with the passage of vegetation season and reveals the lowest concentrations in spring (during germination of plants) and the highest in autumn (Piernik 2003). Our research was carried out in the autumn when investigated abiotic stress had the highest impact. Increased salinity is correlated with a decreased soil respiration and soil microbial biomass and in the consequence contributes to the decreased density and activity of soil microbial population (Shah \& Shah 2011).

The results of our study indicated a presence of halotolerant soil microorganisms able to exist in a salt-free conditions and high soil salt content. Potential of microorganisms for adaptation to different levels of salinity are related to intensive osmoregulation process and in consequence high metabolic activity aiming to protect cells from dehydration (Rietz et al. 2001). Furthermore, lower metabolic efficiency and narrow range of utilized carbon sources might be related with limited activity exo-cellular enzymes which are responsible for $\mathrm{C}$ mineralization (Shah \& Shah 2011). Tripathi et al. (2006) considered that for low productivity of plants in costal salt affected soil low microbial biomass $\mathrm{C}$ and microbial activity is responsible.

Since some plants and microbial populations during their evolution developed adaptive mechanisms to salt stress (Milosević et al. 2012) there is a great interest to exploit their potential to develop and improve alternative agricultural strategies. The development of new technologies in agriculture is based on the extension of the basic knowledge about organisms (plants, bacteria and fungi) able to survive under salinity stress. Halophytes are a good object to investigate these interactions and to explain the physiological and molecular mechanisms determining the resistance of plants to salt stress (Gago et al. 2011). Since populations of microorganisms are able to modulate and ameliorate osmotic stress (Ramadoss et al. 2013), there can be the key factor in the development of agricultural crops in salt affected land.

\section{Conclusions}

We have demonstrated the highest density and total microbial metabolic activity in the rhizosphere. The lower density of endophytes was opposite to their higher metabolic activity compare to soil microorganisms, what confirm high metabolic specificity of this group of microorganisms. To the carbon sources which differentiate metabolic properties of endophytic, rhizosphere and soil populations belongs carboxylic acids.

\section{Acknowledgements}

This investigation was done in frame of COST action FA1103 and financially supported by a grant from the National Science Centre (Poland) (2012/07/B/NZ9/01801).

\section{References}

Andersone U., Samsone I. \& Ievinsh G., 2012, Protection of photosynthesis in coastal salt marsh plants Aster tripolium and Hydrocotyle vulgaris in conditions of increased soil salinity, Environmental and Experimental Biology 10: 89-97.

Bianco C. \& Defez R., 2011, Soil Bacteria Support and Protect Plants Against Abiotic Stresses, [in:] A. Shanker, B. Venkateswarlu (eds), Abiotic Stress in Plants - Mechanisms and Adaptations, Institute of Genetics and Biophysics, "Adriano Buzzati Traverso", Italy, Available from: http://www.intechopen.com/books/ abiotic-stress-in-plants-mechanisms-and-adaptations/ soil-bacteria-support-and-protect-plants-against-abiotic-stresses.

Breitkreuz K. E., Allan W. L., Van Cauwenberghe O. R., Jakobs C., Talibi D., André B. \& Shelp B. J., 2003, A Novel $\gamma$-hydroxybutyrate dehydrogenase: identification and expression of an Arabidopsis cDNA and potential role under oxygen deficiency, Journal of Biological Chemistry 278: 41552-41556.

Campbell C. D., Grayston S. J. \& Hirst D. J., 1997, Use of rhizosphere carbon sources in sole carbon source tests to discriminate soil microbial communities, Journal of Microbiological Methods 30: 33-41.

Classen A. T., Boyle S. I., Haskins K. E., Overby S. T. \& Hart S. C., 2003, Community-level physiological profiles of bacteria and fungi: plate type and incubation temperature influences on contrasting soils, FEMS Microbiolology Ecology 44: 319-328.

Chowdhury N., Marschner P. \& Burns R., 2011, Response of microbial activity and community structure to de- 
creasing soil osmotic and matric potential, Plant Soil 344: 241-254.

El-Swaify S. A., 2000, Soil and Water Salinity, [in:] J. A. Silva, R. Uchida (eds), Plant Nutrient Management in Hawaii's Soils, Approaches for Tropical and Subtropical Agriculture, College of Tropical Agriculture and Human Resources, University of Hawaii at Manoa: 151-158.

Evelin H., Kapoor R. \& Giri B., 2009, Arbuscular mycorrhizal fungi in alleviation of salt stress: a review, Annales Botanici 104: 1263-1280.

FAO, 2008, FAO Land and Plant Nutrition Management Service, Available from: http://www.fao.org/ ag/agl/ agll/spush

Frąc M., Oszust K. \& Lipiec J., 2012, Community level physiological profiles (CLPP), characterization and microbial activity of soil amended with Dairy Sewage Sludge, Sensors 12: 3253-3268.

Gago C., Sousa A. R., Juliao M., Miguel G., Antunes D. C. \& Panagopoulos T., 2011, Sustainable use of energy in the storage of halophytes used for food, International Journal of Energy and Environment 5: 592-599.

Garland J. L. \& Mills A. L., 1991, Classification and characterization of heterotrophic microbial communities on the basis of patterns of community-level sole-carbonsource utilization, Applied and Environmental Microbiology 57: 2351-2359.

Glick B. R., 2012, Plant Growth-Promoting Bacteria: Mechanisms and Applications, Scientifica: Article ID 963401: 1-15.

Gontia-Mishra I. \& Sharma A., 2012, Exogenously supplied osmoprotectants confer enhanced salinity tolerance in rhizobacteria, Journal of Ecobiotechnology 4: 11-13.

Kepel A., Heise W., Pawlaczyk P., Urbański P. \& Górski P., 2013, Aktualizacja listy gatunków roślin objętych ochroną gatunkową oraz wskazania dla ich ochrony [Updating the list of protected plant species and indications for their protection], Polskie Towarzystwo Ochrony Przyrody Salamandra, Poznań.

Kloepper J. W., Rodriguez-Ubana R., Zehnder G. W., Murphy J. F., Sikora E. \& Fernández C., 1999, Plant root-bacterial interactions in biological control of soil borne diseases and potential extension to systemic and foliar diseases, Australasian Plant Pathology 28: 21-26.

Kobayashi D. Y. \& Palumbo J. D., 2000, Bacterial endophytes and their effects on plants and uses in agriculture, [in:] C. W. Bacon, J. F. White (eds), Microbial endophytes, Marcel Dekker, Inc., New York: 199-233.

Ladeiro B., 2012, Saline agriculture in the $21^{\text {st }}$ century: using salt contaminated resources to cope food requirements, Journal of Botany Article ID 310705: 1-7.

Lauber C. L., Strickland M. S., Bradford M. A. \& Noah F. N., 2008, The influence of soil properties on the struc- ture of bacterial and fungal communities across landuse types, Soil Biology \& Biochemistry 40: 2407-2415.

Litchfield C. D. \& Gillevet P. M., 2002, Microbial diversity and complexity in hypersaline environments: a preliminary assessment, Journal of Industrial Microbiology \& Biotechnology 28: 48-55.

Long H. H., Schmidt D. D. \& Baldwin I. T., 2008, Native bacterial endophytes promote host growth in a species-specific manner; phytohormone manipulations do not result in common growth responses, PLoS ONE 3: e2702. doi:10.1371/journal.pone.0002702.

Merkl N. \& Schultze-Kraft R., 2006, Influence of the tropical grass Brachiaria brizantha (Hochst ex. A. Rich.) stapf on bacterial community structure in petroleum contamined soils, International Journal of Soil Science 1: $108-117$.

Milosević N., Marinković J. B. \& Tintor B., 2012, Mitigating abiotic stress in crop plants by microorganisms, Proc. Nat. Sci, Matica Srpska Novi Sad 123: 17-26.

Moradi A., Tahmourespour A., Hoodaji M. \& Khorsandi F., 2011, Effect of salinity on free living - diazotroph and total bacterial populations of two saline soils, African Journal of Microbiology Research 5: 144-148.

Neto D., Carvalho L. M., Cruz C. \& Martins-Loução M. A., 2006, How do mycorrhizas affect $\mathrm{C}$ and $\mathrm{N}$ relationships in flooded Aster tripolium plants?, Plant and Soil 279: 51-63.

Oren A., 2006, Life at high salt concentrations, Prokaryotes 2: 263-282.

Piernik A., 2003, Three types of gradients in the saline ecosystem, Ecological Questions 3: 85-92.

Piernik A., 2006, Growth of three meadow species along a salinity gradient in an inland saline habitat: transplant experiment, Polish Journal of Ecology 54: 117-126.

Piernik A., 2012, Ecological pattern of inland salt marsh vegetation in central Europe, Wydawnictwo Naukowe UMK, Toruń.

Ramadoss D., Lakkineni V. K., Bose P., Ali S. \& Annapurna K., 2013, Mitigation of salt stress in wheat seedlings by halotolerant bacteria isolated from saline habitats, Springer Plus, 2-6.

Rietz D. N., Haynes R. J. \& Chidoma S., 2001, Effects of soil salinity induced under irrigated sugarcane in the Zimbabwean lowveld on soil microbial activity, Proceeding of the South African Sugar Technologists' Association 75: 68-74.

Sardinha M., Müller T., Schmeisky H. \& Joergensen R. G., 2003, Microbial performance in soils along a salinity gradient under acidic conditions, Applied Soil Ecology 23: 237-244.

Sgroy V., Cassán F., Masciarelli O., Del Papa M. F., Lagares A. \& Luna V., 2009, Isolation and characterization of endophytic plant growth-promoting (PGPB) or stress homeostasis-regulating (PSHB) bacteria asso- 
ciated to the halophyte Prosopis strombulifera, Applied Microbiology and Biotechnology 85: 371-81.

Shah S. A. \& Shah Z., 2011, Changes in soil microbial characteristics with elevated salinity, Sarhad Journal of Agriculture 27: 233-244.

Silva Maganhotto de Souza C. M. \& Fay E. F., 2012, Effect of Salinity on Soil Microorganisms, [in:] M. C. Hernandez-Soriano (ed.), Soil Health and Land Use Management, InTech, DOI: 10.5772/2516.

ter Braak C. J. F. \& Šmilauer P., 2002, CANOCO Reference manual and CanoDraw for Windows User's guide: Software for Canonical Community Ordination (version 4.5), Microcomputer Power, Ithaca, NY, USA.

Timmusk S., Paalme V., Pavlicek T., Bergquist J., Vangala A., Danilas T. \& Eviatar N., 2011, Bacterial distribution in the rhizosphere of wild barley under contrasting microclimates, PLoS ONE 6: e17968, doi:10.1371/ journal.pone.0017968.

Tripathi S., Kumari S., Chakraborty A. \& Gupta A., 2006, Microbial biomass and its activities in salt-affected coastal soils, Biology and Fertility of Soils 42: 273277.
Upadhyay S. K., Maurya S. K. \& Singh D. P., 2012, Salinity tolerance in free living plant growth promoting rhizobacteria, Indian Journal of Scientific Research 3: 73-78.

Wang Y. \& Dai Ch.-Ch., 2011, Endophytes: a potential resource for biosynthesis, biotransformation, and biodegradation, Annals of Microbiology 61: 207-215.

Yang X., Ji J., Wang G., Yang S., Zhao Q. \& Lontchi T. J., 2011, Over-expressing Salicornia europaea (SeNHX1) gene in tobacco improves tolerance to salt, African Journal of Biotechnology 10: 16452-16460.

Yang Q., Wang X. \& Shen Y., 2013, Comparison of soil microbial community catabolic diversity between rhizosphere and bulk soil induced by tillage or residue retention, Journal of Soil Science and Plant Nutrition 13: 187-199.

Zinniel D. K., Lambrecht P., Harris N. B., Feng Z., Kuczmarski D., Higley P., Ishimaru C. A., Arunakumari A., Barletta R. G. \& Vidaver A. K., 2002, Isolation and characterization of endophytic colonizing bacteria from agronomic crops and prairie plants, Applied and Environmental Microbiology 68: 2198-2208. 
